\title{
Pengaruh Komitmen Organisasi Terhadap Kinerja Penyuluh Keluarga Berencana (PKB) Di BKKBN Propinsi Sulawesi Tenggara
}

\author{
Faidha1 \\ ${ }^{1}$ Widyaiswara Perwakilan BKKBN Sulawesi Tenggara \\ Email: drsfaidha@gmail.com
}

\begin{abstract}
Abstrak; Fenomena yang terjadi program yang dicanangkan oleh BKKBN Propinsi Sulawesi Tenggara berhadapat dengan beberapa masalah yaitu; komitmen organisasional pada setiap pegawai berbeda, diantaranya beberapa pegawai memutuskan untuk berkomitmen pada suatu organisasi karena merasa insentif/gaji yang diterima sesuai dengan kinerja yang diberikan, kemudian beberapa pegawai yang memutuskan untuk berkomitmen karena merasa kewajiban untuk tetap berada dalam perusahaan tersebut karena ia dibutuhkan dan ada pula yang berkomitmen karena apabila dia meninggalkan kantor akan menambah biaya yang lebih besar dibanding tetap bekerja di kantor tersebut. Penelitian ini bermaksud mengkaji pengaruh komitmen organisasi terhadap kinerja penyuluh Keluarga Berencana di Wilayah Sulawesi Tenggara. Penelitian dilakukan melalui pendekatan kuantitatif, dimana sampel dipilih menurut kebutuhan sebanyak 35 orang. Instrumen penelitian menggunakan kuesioner. Selanjutnya penelitian menggunakan uji validitas (test of validity) dan uji reliabilitas (test of realiability). Data kemudian diolah menggunakan Uji Validitas dan Uji Reabilitas, Dengan menguji pengaruh komitmen organisasi terhadap kinerja pegawai penyuluh. Hasil penelitian menunjukkan bahwa hubungan komitmen organisasi yang terdiri dari affective commitment, continuance commitment dan normative commitment ditingkatkan maka meningkatkan kinerja penyuluh. Sebaliknya, apabila komitmen organisasi tidak baik, akibatnya akan berdampak pada hasil kinerja penyuluh yang tidak maksimal.
\end{abstract}

Kata Kunci: Komitmen Organisasi, Kinerja, Sulawesi Tenggara

\begin{abstract}
The phenomenon that occurred the program launched by bkkbn southeast Sulawesi province can be with several problems, namely; Organizational commitments to each employee are different, including some employees decide to commit to an organization because it feels incentives / salaries received in accordance with the performance given, then some employees who decide to commit because they feel the obligation to remain in the company because it is needed and some are committed because if he leaves the office will add a greater cost than staying in the office. This study intends to examine the influence of the organization's commitment to the performance of Family Planning extension in Southeast Sulawesi. The research was conducted through a quantitative approach, where samples were selected according to the needs of 35 people. Research instruments using questionnaires. Furthermore, the study used validity test (test of validity) and reliability test (test of realiability). The data is then processed using Validity Test and Reliability Test, by testing the influence of the organization's commitment to the performance of extension workers. The results showed that the relationship of organizational commitment consisting of affective commitment, continuance commitment and normative commitment is improved, thus improving the performance of the extension. Conversely, if the commitment of the organization is not good, the consequences will have an impact on the results of the extension performance is not maximized.
\end{abstract}

Keywords: Organizational Commitment, Performing, South East Sulawesi 


\section{Pendahuluan}

Komitmen karyawan merupakan salah satu kunci yang turut menentukan berhasil tidaknya suatu organisasi untuk mencapai tujuannya. Karyawan yang mempunyai komitmen pada organisasi biasanya mereka menunjukan sikap kerja yang penuh perhatian terhadap tugasnya, mereka sangat memiliki tanggung jawab untuk melaksanakan tugas-tugas serta sangat loyal terhadap perusahaan.

Komitmen organisasi adalah dorongan dari dalam individu untuk berbuat sesuatu agar dapat menunjang keberhasilan organisasi sesuai dengan tujuan dan lebih mengutamakan kepentingan organisasi dibandingkan dengan kepentingan sendiri (Weiner dalam Coryanata, 2004). Rachmawati (2009) mengartikan komitmen organisasional sebagai sikap yang menunjukkan "loyalitas" karyawan dan merupakan proses berkelanjutan bagaimana seorang anggota organisasi mengekspresikan perhatian mereka kepada kesuksesan dan kebaikan organisasinya. Menurut Robert dan Kinicki (dalam Robert Kreitner, 2011) bahwa komitmen organisasi adalah cerminan dimana seorang karyawan dalam mengenali organisasi dan terikat kepada tujuan-tujuannya. Sedangkan menurut Sopiah (2008) menyatakan bahwa komitmen organisasi adalah suatu ikatan psikologis pada karyawan yang ditandai dengan adanya kepercayaan dan penerimaan yang kuat atas tujuan dan nilai-nilai organisasi, kemauan untuk mengusahakan tercapainya kepentingan organsisasi dan keinginan untuk mempertahankan kedudukan sebagai anggota organisasi. Fred (2006) bahwa komitmen organisasi memiliki pengaruh terhadap kinerja, absensi, komitmen, dan pergantian karyawan. Faktor pembentuk variabel komitmen organisasi dalam penelitian ini adalah menurut Robbins dan Judge (2009) terbagi menjadi tiga, yaitu 1) affective commitment, 2) continuance commitment dan 3) normative commitment.

Affective commitment merupakan perasaan emosional untuk organisasi dan keyakinan akan nilai-nilainya. Continuance commitment merupakan nilai ekonomi yang dirasakan bila bertahan dalam suatu organisasi dibandingkan dengan meninggalkan organisasi tersebut. Normative commitment merupakan kewajiban untuk bertahan dalam organisasi karena alasan moral atau etis. Selanjutnya penelitian ini berusaha mengartikulasi, menguji dan menganalisis komitmen organisasi yang dilakukan oleh Feri Arif Novan Telaumbanua et al (2019), Rustamadji et al (2019) dan Folorunso, 0.0 et al (2018), menyimpulkan bahwa komitmen organisasi berpengaruh signifikan terhadap kinerja pegawai. Namun penelitian berbeda yang dilakukan oleh Aruna Shantha Gamage (2019), yang menyimpulkan bahwa komitmen organisasi tidak berpengaruh signifikan terhadap kinerja pegawai.

Lebih lanjut Robbins (2008) mendefenisikan kinerja yaitu suatu hasil yang dicapai oleh pegawai dalam pekerjaannya menurut kriteria tertentu yang berlaku untuk suatu pekerjaan. Kinerja adalah tingkatan pencapaian hasil atas pelaksanaan tugas tertentu. Simanjutak (2005). Mathis dan Jackson (2011:81) Kinerja (Perfomance Appraisal-PA) adalah proses evaluasi seberapa baik karyawan mengerjakan pekerjaan dibandingkan dengan satu set standar, dan kemudian mengkomunikasikannya dengan para karyawan. Kinerja adalah kemampuan pegawai menyelesaikan kewajibannya sesuai dengan waktu dan rencana atau 
sesuai dengan yang diharapkan. Pengukuran kinerja karyawan dapat dilakukan terhadap kinerja yang nyata dan terukur Abdullah, (2014:146). Faktor pembentuk variabel kinerja pegawai dalam penelitian ini yang dikemukakan oleh Sutrisno, (2010:172-173) yang terdiri dari 1) kuantitas kerja, 2) kualitas kerja, 3) ketangguhan, 4) kerja sama dan 5) ketepatan waktu.

Berdasarkan research gap pada dengan belum adanya konsistensi dari hasil penelitian empiris terdahulu mengenai pengaruh komitmen organisasi terhdap kinerja, argumen yang dapat dipersepsikan penulis bahwa hasil penelitian tersebut disebabkan oleh keragaman dalam indikator pengukuran variabel, obyek yang dikaji, metodologi dan dasar teori yang digunakan sehingga penelitian ini menjadi penting untuk dilakukan untuk pengujian kembali terhadap kontradiksi hasil temuan tersebut.

Dengan demikian dipandang perlu adanya penelitian lanjutan khususnya pada penyuluh pegawai BKKBN di Sulawesi Tenggara. Alasan memilih objek ini karena BKKBN di Sulawesi Tenggara tepat dalam penerapan melakukan komitmen organisasi terhadap kinerja. Fenomena yang terjadi di BkkbN Propinsi Sulawesi tenggara secara umum terjadi adalah komitmen organisasional pada setiap pegawai berbeda, diantaranya beberapa pegawai memutuskan untuk berkomitmen pada suatu organisasi karena merasa insentif/gaji yang diterima sesuai dengan kinerja yang diberikan, kemudian beberapa pegawai yang memutuskan untuk berkomitmen karena merasa kewajiban untuk tetap berada dalam perusahaan tersebut karena ia dibutuhkan dan ada pula yang berkomitmen karena apabila dia meninggalkan kantor akan menambah biaya yang lebih besar dibanding tetap bekerja di kantor tersebut.

Sehingga masalah komitmen organisasional perlu adanya penelitian lebih lanjut yang berkaitan dengan keadilan organisasional agar dari hasil penelitian tersebut dapat memberikan solusi empiris tentang fenomena tersebut. Sehingga proses dalam menciptakan komitmen organisasional adalah persepsi keadilan. Penelitian ini bermaksud mengkaji pengaruh komitmen organisasi terhadap kinerja Penyuluh Lapangan Keluarga Berencana (PLKB) BKKBN Propinsi Sulawesi Tenggara, dengan tujuan untuk memberikan penilaian komprehensif terkait kaitan antara komitmen organisasional terhadap kinerja Penyuluh.

\section{Metode Penelitian}

Penelitian ini dirancang dengan maksud untuk memberikan penjelasan hubungan kausal antar variabel melalui pengujian hipotesis, dengan demikian maka pendekatan penelitian ini adalah metode deskriptif dalam bentuk explanation dengan menggunakan pendekatan kuantitatif. Sampel ditentukan dengan menggunakan teknik pengambilan sampel Non-probability Sampling melalui pendekatan Purposive Sampling. Sampel kemudian dipilih melalui kriteria yang berdasarkan pertimbangan (judgement) tertentu atau quota. Dengan begitu, penelitian ini menentukan quota jumlah sampel adalah 35 orang Penyuluh Keluarga Berencana (PKB) BKKBN pada wilayah kerja Sulawesi Tenggara. 
Data dikumpulkan dengan dua cara yakni Kuesioner dan Wawancara kepada sampel yang telah ditentukan. Data kemudian dioleh melalui mekanisme pengukuran menggunakan 5 Point Likert Scale. Karena itu, untuk menguji kuesioner sebagai instrumen penelitian maka digunakan uji validitas (test of validitu) dan uji reliabilitas (test of realiability). Selajutnya data akan diolah menggunakan Uji Validitas dan Uji Reabilitas, Dengan menguji pengaruh komunikasi interpersonal terhadap kinerja pegawai penyuluh BKKBN di Sulawesi Tenggara. Adapun model persamaan yang akan diestimasi dengan menggunakan analisis regresi sederhana:

\section{Variate value $(\mathrm{Y})=\mathrm{W}_{1} \mathrm{X}_{1}+\mathrm{W}_{\mathbf{n}} \mathrm{X}_{\mathbf{n}}$ \\ (Hair et al. , 2010)}

di mana: Variate value = nilai variasi perubahan variable bebas (dependent); X1- Xn = Variasi variabel tertimbang (weight); Xn adalah variabel yang diamati dan Wn adalah Weight determined yang ditentukan dengan teknik multivariat. Selanjutnya model persamaan yang dapat dinyatakan secara matematis tersebut ditransformasi atau dioperasionalkan dalam penelitian ini sebagai berikut:

\section{$\mathrm{KP}=\mathrm{W} 1 \mathrm{Ko}$}

Dimana:

$\begin{array}{ll}\text { KP } & =\text { Kinerja Penyuluh } \\ \text { KO } & =\text { Komitmen Orgnisasi } \\ \text { W1,W2 \&W3 } & =\text { Weight determined atau Regression weight (standardized beta) }\end{array}$

Setelah model penelitian diestimasi maka akan diperoleh nilai dan besaran dari masing-masing parameter dalam model persamaan diatas. Nilai dari parameter positif atau negatif selanjutnya akan digunakan untuk menguji hipotesis penelitian.

\section{Hasil Penelitian dan Pembahasan}

\section{a. Profil Kinerja Penyuluh Keluarga Berencana Sulawesi Tenggara}

Program Keluarga Berencana Nasional di Sulawesi Tenggara secara resmi dimulai pada Pelita III (1979/1980) sesuai dengan Keutusan presiden No. 38 tahun 1978 dan surat keputusan kepala BKKBN Nomor: 26/SK-1/1979 bersama 11 Provinsi lainnya di Indonesia yang lazim disebut dengan Provinsi Luar Jawa-Bali II (LJB-II). Pada tahun 1980 dibentuk kelembagaan BKKBN Provinsi dan tahun 1981 di semua Kabupaten dibentuk Satuan Tugas KB yang diketuai oleh Kepala Bagian Kesra Tk. II dan pada tahun 1982/1983 secara bersamaan dibentuk BKKBN Kabupaten dan Koordinator Petugas Lapangan Keluarga Berencana. Pada tahun 1983/1984 nama Koordinator PLKB berubah menjadi Pengawas PLKB. 
Pelaksanaan Keluarga Berencana secara Nasional semakin berkembang dimana pada era reformasi terjadi suatu perubahan kebijakan Gerakan KB Nasional kembali menjadi Program KB Nasional, sesuai dengan Visi dan Misi yang baru. Demikian pula kelembagaan/organisasi BKKBN ikut mengalami penyempurnaan berdasarkan Kepres 166 Tahun 2000. Zaman semakin berubah, dimensi Program KBpun ikut berubah. Tercatat pada akhir tahun 2003 Kelembagaan serta program KB tingkat Kabupaten/Kota diserahkan kepada pemerintahan daerah, yang ditandai dengan Penyerahan P3D dari Pemerintah Pusat ke Pemerintahan Daerah, dan itu berarti seluruh tanggung jawab pelaksanaan Program KB ada di tangan pemerintahan Kabupaten/Kota.

Termasuk pengelolaan dan pembinaan PNS yang ada. Sejalan dengan perkembangan program kependudukan, Keluarga Berencana dan Pembangunan Keluarga yang terbaru berdasarkan Undang- Undang Nomor 23 Tahun 2014 dan dikuatkan dengan Surat Edaran Menteri Dalam Negeri Nomor 18 tahun 2016 tentang Pemerintahan Daerah yang mengamanatkan adanya Dinas Pengendalian Penduduk dan KB, baik di tingkat provinsi maupun di kabupaten/kota yang terbagi dalam beberapa tipologi yaitu Tipe A, B dan C. Hal ini ditentukan berdasarkan kriteria umum dan kriteria khusus yang dimiliki masing- masing provinsi atau kabupaten/ kota. Kelembagaan BKKBN saat ini diharapkan dapat memperkuat peran strategis menjalankan program Kependudukan, Keluarga Berencana dan Pembangunan Keluarga sehingga menindaklanjuti hal tersebut dikeluarkan Peraturan Kepala Badan Kependudukan dan Keluarga Berencana Nasional No. 163 Tahun 2016 tentang Pedoman Nomenklatur, Tugas dan Fungsi Dinas Pengendalian Penduduk dan Keluarga Berencana di Provinsi, Kabupaten dan Kota bahwa perangkat daerah yang menyelenggarakan urusan pemerintahan bidang pengendalian penduduk dan keluarga berencana nomenklaturnya adalah Dinas Pengendalian Penduduk dan Keluarga Berencana.

Sedangkan ketentuan mengenai kedudukan, struktur organisasi, tugas dan fungsi serta tata kerjanya selanjutnya ditetapkan dengan Peraturan Kepala Daerah. Badan Kependudukan Keluarga Berencana Nasional Propinsi Sulawesi Tenggara bersama Kementrian Dalam Negeri, Sub Direktorat Pengendalian Penduduk dan Keluarga Berencana dan Biro Hukum Organisasi dan Humas BKKBN telah melakukan sosialisasi dan fasilitasi pembentukan kelembagaan program kependudukan dan keluarga berencana di Kabupaten dan Kota se-Sulawesi Tenggara dan dilaporkan di akhir Desember tahun 2016 ini seluruh Kabupaten Kota se Sulawesi Tenggara telah menyelsaikan Ranperda tersebut. Nomenklatur kelembagaan dan tenaga pengelola program KKBPK dapat diuraikan pada tabel 1. 
Tabel 1. Kelembagaan Organisasi Perangkat Daerah (OPD)-KB Sultra

\begin{tabular}{|c|c|c|c|c|c|}
\hline \multirow{2}{*}{ No. } & \multirow{2}{*}{$\begin{array}{c}\text { Wilayah } \\
\text { Prov \& } \\
\text { Kab/Kota } \\
\end{array}$} & \multicolumn{3}{|c|}{ Perda / Perwali } & \multirow[t]{2}{*}{ Kepala OPD-KB } \\
\hline & & Nomor & Nomenklatur & Tipe & \\
\hline 1 & Kab.Kolaka & $\begin{array}{c}5 \text { Tahun } 2016 \\
(21 / 10 / 16) \\
\end{array}$ & $\begin{array}{c}\text { Dinas Pengendalian } \\
\text { Penduduk dan KB }\end{array}$ & $\mathrm{B}$ & $\begin{array}{c}\text { dr. Hj. Muliati } \\
\text { Habibullah, M.Si }\end{array}$ \\
\hline 2 & Kab.Konawe & $\begin{array}{l}6 \text { Tahun } 2016 \\
(5 / 12 / 2016)\end{array}$ & $\begin{array}{l}\text { Dinas Pengendalian } \\
\text { Penduduk dan KB }\end{array}$ & $\mathrm{A}$ & $\begin{array}{l}\text { Dra. Hj. Asriani Porosi, } \\
\text { M.Si }\end{array}$ \\
\hline 3 & Kab.Muna & $\begin{array}{l}6 \text { Tahun } 2016 \\
(5 / 11 / 2016) \\
\end{array}$ & $\begin{array}{c}\text { Dinas Pengendalian } \\
\text { Penduduk dan KB }\end{array}$ & B & Drs. Muh Safei, M.Si \\
\hline 4 & Kab.Buton & $\begin{array}{c}5 \text { Tahun } 2016 \\
(21 / 10 / 16) \\
\end{array}$ & $\begin{array}{c}\text { Dinas Pengendalian } \\
\text { Penduduk dan KB }\end{array}$ & $\mathrm{B}$ & Nasbah, SE \\
\hline 5 & Kota Kendari & $\begin{array}{l}5 \text { Tahun } 2016 \\
(17 / 10 / 2016)\end{array}$ & $\begin{array}{l}\text { Dinas Pengendalian } \\
\text { Penduduk dan KB }\end{array}$ & $\mathrm{B}$ & Drs. Boy Azis \\
\hline 6 & Kota Baubau & $\begin{array}{l}5 \text { Tahun } 2016 \\
(5 / 12 / 2016)\end{array}$ & $\begin{array}{l}\text { Dinas Pengendalian } \\
\text { Penduduk dan KB }\end{array}$ & B & Drs. Sudarman., M.Si \\
\hline 7 & $\begin{array}{c}\text { Kab.Konawe } \\
\text { Selatan }\end{array}$ & $\begin{array}{l}8 \text { Tahun } 2016 \\
(12 / 10 / 2016)\end{array}$ & $\begin{array}{c}\text { Dinas Pengendalian } \\
\text { Penduduk dan KB }\end{array}$ & $\mathrm{B}$ & Najib, S.Sos \\
\hline 8 & Kab.Kolaka Utara & $\begin{array}{l}3 \text { Tahun } 2016 \\
(15 / 9 / 2016)\end{array}$ & $\begin{array}{c}\text { Dinas Pengendalian } \\
\text { Penduduk dan KB }\end{array}$ & $\mathrm{B}$ & Saimah, SH \\
\hline 9 & Kab.Wakatobi & $\begin{array}{l}5 \text { Tahun } 2016 \\
(17 / 11 / 2016)\end{array}$ & $\begin{array}{l}\text { Dinas Pengendalian } \\
\text { Penduduk dan KB }\end{array}$ & A & Drs. Syafiuddin, M.Si \\
\hline 10 & Kab.Bombana & $\begin{array}{l}3 \text { Tahun } 2016 \\
(24 / 11 / 2016)\end{array}$ & $\begin{array}{l}\text { Dinas Pengendalian } \\
\text { Penduduk dan KB }\end{array}$ & $\mathrm{B}$ & Drs. A z i s., M.Si \\
\hline 11 & $\begin{array}{l}\text { Kab.Konawe } \\
\text { Utara }\end{array}$ & $\begin{array}{l}9 \text { Tahun } 2016 \\
(4 / 10 / 2016)\end{array}$ & $\begin{array}{l}\text { Dinas Pengendalian } \\
\text { Penduduk dan KB }\end{array}$ & $\mathrm{B}$ & $\begin{array}{l}\text { Drs. H. M. Kasim } \\
\text { Pagala, M.Si }\end{array}$ \\
\hline 12 & Kab.Buton Utara & $\begin{array}{l}6 \text { Tahun } 2016 \\
(4 / 11 / 2016)\end{array}$ & $\begin{array}{l}\text { Dinas Pengendalian } \\
\text { Penduduk dan KB }\end{array}$ & $\mathrm{C}$ & Mansyur, S.Sos., M.Si \\
\hline 13 & $\begin{array}{l}\text { Kab. Kolaka } \\
\text { Timur }\end{array}$ & $\begin{array}{l}21 \text { Tahun } 2016 \\
(21 / 11 / 2016)\end{array}$ & $\begin{array}{c}\text { Dinas Pengendalian } \\
\text { Penduduk dan KB }\end{array}$ & $\mathrm{B}$ & Nasruddin, SE., M.Si \\
\hline 14 & $\begin{array}{l}\text { Kab. Konawe } \\
\text { Kepulauan }\end{array}$ & $\begin{array}{l}2 \text { Tahun } 2016 \\
(21 / 11 / 2016)\end{array}$ & $\begin{array}{c}\text { Dinas Pengendalian } \\
\text { Penduduk, KB, PP dan } \\
\text { PA }\end{array}$ & $\mathrm{C}$ & $\begin{array}{c}\text { Dra.Hj. Sitti Muhariah., } \\
\text { M.S }\end{array}$ \\
\hline 15 & Kab. Muna Barat & $\begin{array}{l}1 \text { Tahun } 2016 \\
(7 / 10 / 2016)\end{array}$ & $\begin{array}{c}\text { Dinas Pengendalian } \\
\text { Penduduk, KB, PP dan } \\
\text { PA }\end{array}$ & $\mathrm{C}$ & $\begin{array}{l}\text { La Ode Muhlisi, A.Kep, } \\
\text { M.Kes }\end{array}$ \\
\hline 16 & $\begin{array}{c}\text { Kab. Buton } \\
\text { Tengah }\end{array}$ & $\begin{array}{l}\text { 12 Tahun } 2016 \\
(11 / 11 / 2016)\end{array}$ & $\begin{array}{c}\text { Dinas Pengendalian } \\
\text { Penduduk dan KB }\end{array}$ & B & Drs. Syamsuddin, M \\
\hline 17 & $\begin{array}{l}\text { Kab. Buton } \\
\text { Selatan }\end{array}$ & $\begin{array}{l}2 \text { Tahun } 2016 \\
(28 / 10 / 2016)\end{array}$ & $\begin{array}{l}\text { Dinas Pengendalian } \\
\text { Penduduk dan KB }\end{array}$ & $\mathrm{B}$ & La Asari, SP., M.Si \\
\hline
\end{tabular}


Tabel 2. Jumlah Tenaga Pelaksana dan Pengelola

\begin{tabular}{|c|c|c|c|c|c|c|}
\hline \multirow{2}{*}{ No. } & \multirow{2}{*}{ Kab./Kota } & \multicolumn{4}{|c|}{$\begin{array}{l}\text { Tenaga Pelaksana dan Pengola } \\
\text { Program } \\
\end{array}$} & \multirow[t]{2}{*}{$\begin{array}{l}\text { Jumlah } \\
(5+6)\end{array}$} \\
\hline & & Dokter & Bidan & PPLKB & $\begin{array}{l}\text { PKB/P } \\
\text { LKB }\end{array}$ & \\
\hline 1 & 2 & 3 & 4 & 5 & 6 & 7 \\
\hline 1 & Kolaka & 28 & 120 & 7 & 23 & 30 \\
\hline 2 & Konawe & 57 & 294 & 22 & 56 & 78 \\
\hline 3 & Muna & 11 & 60 & 0 & 14 & 14 \\
\hline 4 & Buton & 20 & 107 & 0 & 10 & 10 \\
\hline 5 & Kota Kdi & 26 & 189 & 10 & 20 & 30 \\
\hline 6 & Kota Bau-Bau & 26 & 109 & 0 & 10 & 10 \\
\hline 7 & Konsel & 30 & 299 & 20 & 22 & 42 \\
\hline 8 & Kolut & 14 & 187 & 0 & 56 & 56 \\
\hline 9 & Wakatobi & 22 & 125 & 8 & 20 & 28 \\
\hline 10 & Bombana & 37 & 165 & 22 & 73 & 95 \\
\hline 11 & Konut & 16 & 78 & 3 & 2 & 5 \\
\hline 12 & Butur & 11 & 144 & 6 & 2 & 8 \\
\hline 13 & Kolaka Timur & 9 & 50 & 12 & 12 & 24 \\
\hline 14 & Konawe Kepulauan & 8 & 65 & 0 & 38 & 38 \\
\hline 15 & Muna Barat & 8 & 30 & 0 & 2 & 2 \\
\hline 16 & Buton Tengah & 7 & 86 & 0 & 7 & 7 \\
\hline 17 & Buton Selatan & 2 & 74 & 7 & 1 & 8 \\
\hline & Sultra & 306 & 1.119 & 117 & 368 & 485 \\
\hline
\end{tabular}

Sumber: Data Kepegawaian BKKBN Prov. Sultra 2016

\section{Keterangan:}

1. Ratio PKB/PLKB (368) terhadap jumlah Desa (2.248) adalah 1 : 5; yang berarti 1 PKB/PLKB membina sekitar 5 Desa/Kelurahan.

2. Ratio PPLKB/KUPT (117) terhadap jumlah Kecamatan 212 adalah $1: 2$ yang berarti 1 PPLKB/UPT membina sekitar 2 Kecamatan.

Berbagai keberhasilan yang di capai dalam pelaksanaan Program KB Nasional sampai di lini lapangan tidak terlepas dari dukungan dan peran serta Institusi Masyarakat pedesaan seperti PPKBD dan Sub PPKBD. PPKBD di Sulawesi Tenggara dibentuk sejak tahun 1983/1984 dan Sub PPKBD pada tahun 1986/1987. Perkembangan institusi ini cukup menggambarkan baik dalam jumlah maupun perannya. Jumlah PPKBD dan Sub PPKBD sesuai data pada tabel 3. 
Tabel 3. Jumlah PPKBD dan Sub PPKBD

\begin{tabular}{|c|l|c|c|}
\hline No & Kab/Kota & PPKBD & Sub PPKBD \\
\hline 1 & Kolaka & 135 & 445 \\
\hline 2 & Konawe & 361 & 1.108 \\
\hline 3 & Muna & 151 & 334 \\
\hline 4 & Buton & 95 & 285 \\
\hline 5 & Kota Kendari & 64 & 349 \\
\hline 6 & Kota Bau-Bau & 361 & 180 \\
\hline 7 & Konawe Selatan & 133 & 1.341 \\
\hline 8 & Kolaka Utara & 100 & 519 \\
\hline 9 & Wakatobi & 139 & 274 \\
\hline 10 & Bombana & 146 & 443 \\
\hline 11 & Konawe Utara & 90 & 442 \\
\hline 12 & Buton Utara & 133 & 250 \\
\hline 13 & Kolaka Timur & 96 & 502 \\
\hline 14 & Konawe Kepulauan & 86 & 292 \\
\hline 15 & Muna Barat & 77 & 193 \\
\hline 16 & Buton Tengah & $\mathbf{7 0}$ & 303 \\
\hline 17 & Buton Selatan & Total & 262 \\
\hline & & & $\mathbf{2 8 0}$ \\
\hline
\end{tabular}

Sumber : Data Kepegawaian BKKBN Prov. Sultra 2016

Keterangan:

1. Ratio PPKBD (2.280) terhadap jumlah PUS (455.758) adalah $1: 200$; Rasio Sub PPKBD (terhadap PUS adalah $1: 61$ )

2. Ratio PPKBD terhadap PA (271.487) adalah 1 : 128; Sub PPKBD terhadap PA adalah $1: 41$

\section{b. Pengaruh Komitmen Organisasi Terhadap Kinerja Penyuluh Keluarga Berencana (PKB)}

Penelitian ini dilakukan di BKKBN Propinsi Sulawesi Tenggara. Dalam penelitian ini terdapat 35 sampel/responden Penyuluh Keluarga Berencana PNS secara keseluruhan yang terdiri dari 17 Kabupaten/ Kota di Sulawesi Tenggara. Hingga akhir penelitian ini dilakukan, responden yang mengembalikan angket penelitian adalah 35 orang atau 100 persen dengan mengisi angket secara lengkap. Dengan demikian, secara metodologis dikatakan layak untuk dilakukan pengujian dan pembahasan hasil penelitian. 


\section{Komitmen Organisasi (X1)}

Komitmen organisasi yang dimaksud adalah suatu keadaan dimana seorang karyawan memihak organisasi tertentu serta tujuan-tujuan dan keinginannya untuk mempertahankan keanggotaan dalam organisasi tersebut. (Robbins dan Judge (2009). Komitmen organisasi dalam penelitian ini 3 indikator dan 9 item yang meliputi: affective commitment, continuance commitment dan normative commitment. Rekapitulasi jawaban responden terhadap komitmen organisasi dapat diuraikan sebagai berikut:

Tabel 4. Deskripsi Jawaban Terhadap Variabel Komitmen Organisasi (X1)

\begin{tabular}{|c|c|c|c|c|c|c|c|c|c|c|c|c|c|}
\hline \multirow{2}{*}{$\begin{array}{l}\text { Indikator } \\
\text { variabel }\end{array}$} & \multirow{3}{*}{$\begin{array}{l}\text { Item } \\
\text { Butir }\end{array}$} & \multicolumn{10}{|c|}{ Frekuensi (f) dan Persentase (\%) Jawaban Responden } & \multirow[t]{3}{*}{$\begin{array}{l}\text { Rerata } \\
\text { (Mean) }\end{array}$} & \\
\hline & & \multicolumn{2}{|c|}{ STS (1) } & \multicolumn{2}{|c|}{ TS (2) } & \multicolumn{2}{|c|}{$\mathrm{N}(3)$} & \multicolumn{2}{|c|}{$S(4)$} & \multicolumn{2}{|c|}{ SS (5) } & & \\
\hline \multirow{4}{*}{$\begin{array}{c}\text { Affective } \\
\text { commitment } \\
\text { (X1.1) }\end{array}$} & & $\mathrm{F}$ & $\%$ & $\mathrm{f}$ & $\%$ & $\mathrm{~F}$ & $\%$ & $\mathrm{~F}$ & $\%$ & $\mathrm{f}$ & $\%$ & & \\
\hline & $\mathrm{X} 1.1 .1$ & 0 & $\begin{array}{l}0,0 \\
0\end{array}$ & 0 & 0,00 & 2 & 5,7 & 19 & 54,3 & 14 & 40,0 & 4,34 & \multirow{3}{*}{4,17} \\
\hline & $\mathrm{X} 1.1 .2$ & 0 & $\begin{array}{l}0,0 \\
0\end{array}$ & 1 & 2,90 & 3 & 8,6 & 22 & 62,9 & 9 & 25,7 & 4,11 & \\
\hline & $\mathrm{X} 1.1 .3$ & 0 & $\begin{array}{l}0,0 \\
0\end{array}$ & 1 & 2,90 & 6 & 17,1 & 18 & 51,4 & 10 & 28,6 & 4,06 & \\
\hline \multirow{3}{*}{$\begin{array}{c}\text { Continuance } \\
\text { commitment } \\
\text { (X1.2) }\end{array}$} & $\mathrm{X} 1.2 .1$ & 0 & $\begin{array}{l}0,0 \\
0\end{array}$ & 4 & 11,4 & 6 & 17,1 & 17 & 48,6 & 8 & 22,9 & 3,83 & \multirow{3}{*}{4,07} \\
\hline & $\mathrm{X} 1.2 .2$ & 0 & $\begin{array}{l}0,0 \\
0\end{array}$ & 1 & 2,90 & 2 & 5,70 & 20 & 57,1 & 12 & 34,3 & 4,23 & \\
\hline & $\mathrm{X} 1.2 .3$ & 0 & $\begin{array}{l}0,0 \\
0\end{array}$ & 0 & 0,00 & 4 & 11,4 & 22 & 62,9 & 9 & 25,7 & 4,14 & \\
\hline \multirow{3}{*}{$\begin{array}{l}\text { Normative } \\
\text { commitment } \\
\text { (X1.3) }\end{array}$} & $\mathrm{X} 1.3 .1$ & 0 & $\begin{array}{l}0,0 \\
0\end{array}$ & 4 & 11,4 & 9 & 25,7 & 17 & 48,6 & 5 & 14,3 & 3,66 & \multirow{3}{*}{3,84} \\
\hline & $\mathrm{X} 1.3 .2$ & 0 & $\begin{array}{l}0,0 \\
0\end{array}$ & 0 & 0,00 & 1 & 2,90 & 23 & 65,7 & 11 & 31,4 & 4,29 & \\
\hline & $\mathrm{X} 1.3 .3$ & 0 & $\begin{array}{l}0,0 \\
0\end{array}$ & 2 & 5,70 & $\begin{array}{l}1 \\
6 \\
\end{array}$ & 45,7 & 12 & 34,3 & 5 & 14,3 & 3,57 & \\
\hline \multicolumn{12}{|c|}{ Rerata Variabel Komitmen Organisasi (X1) } & \multicolumn{2}{|c|}{4,03} \\
\hline
\end{tabular}

Sumber: Data Primer (kuisioner) diolah, tahun 2021

Berdasarkan rekapitulasi jawaban responden atas variabel komitmen organisasi pada BkkbN Propinsi Sulawesi Tenggara seperti yang disajikan pada Tabel 4 diatas, menunjukkan bahwa deskripsi jawaban responden secara keseluruhan tentang komitmen organisasi menyatakan sudah sangat baik dengan nilai rerata 4,03. Artinya bahwa mayoritas responden menyatakan secara secara keseluruhan mengenai penerapan komitmen organisasi meliputi: affective commitment, continuance commitment dan normative commitment sudah terlaksana dengan baik. 


\section{Kinerja Pegawai}

Kinerja adalah penilaian pegawai BKKBN Propinsi Sulawesi Tenggara atas hasil akhir dari aktivitas kerja yang dapat diukur melalui kemampuan kerja, kecakapan, keahlian dan sikap seorang yang diukur dengan 5 item pertanyaan yang terdiri dari kuantitas kerja, kualitas kerja, ketangguhan, kerja sama dan ketepatan waktu. Rekapitulasi jawaban responden terhadap kinerja diuraikan sebagai berikut:

Tabel 5. Deskripsi Jawaban Terhadap Variabel Kinerja

\begin{tabular}{|c|c|c|c|c|c|c|c|c|c|c|c|c|}
\hline \multirow{2}{*}{$\begin{array}{c}\text { Indikator } \\
\text { variabel }\end{array}$} & \multirow{2}{*}{$\begin{array}{l}\text { Item } \\
\text { Butir }\end{array}$} & \multicolumn{10}{|c|}{ Frekuensi (f) dan Persentase (\%) Jawaban Responden } & \multirow[t]{2}{*}{$\begin{array}{l}\text { Rerata } \\
\text { (Mean) }\end{array}$} \\
\hline & & \multicolumn{2}{|c|}{ STS (1) } & \multicolumn{2}{|c|}{ TS (2) } & \multicolumn{2}{|c|}{$\mathrm{N}(3)$} & \multicolumn{2}{|c|}{$S(4)$} & \multicolumn{2}{|c|}{ SS (5) } & \\
\hline \multirow{6}{*}{$\begin{array}{l}\text { Kinerja } \\
(Y)\end{array}$} & & $\mathrm{F}$ & $\%$ & $\mathrm{f}$ & $\%$ & $\mathrm{f}$ & $\%$ & $\mathrm{~F}$ & $\%$ & $\mathrm{f}$ & $\%$ & \\
\hline & Y1.1 & 0 & 0,00 & 0 & 0,00 & 8 & 22,9 & 22 & 62,9 & 5 & 14,3 & 3,91 \\
\hline & Y1.2 & 0 & 0,00 & 1 & 2,90 & 6 & 17,1 & 25 & 71,4 & 3 & 8,60 & 3,86 \\
\hline & Y1.3 & 0 & 0,00 & 3 & 8,60 & 14 & 40,0 & 16 & 45,7 & 2 & 5,7 & 3,49 \\
\hline & Y1.4 & 0 & 0,00 & 3 & 8,60 & 5 & 14,3 & 26 & 74,3 & 1 & 2,90 & 3,71 \\
\hline & Y1.5 & 0 & 0,00 & 0 & 0,00 & 3 & 8,60 & 27 & 77,1 & 5 & 14,3 & 4,06 \\
\hline \multicolumn{12}{|c|}{ Rerata Variabel Kinerja (Y) } & 3,81 \\
\hline
\end{tabular}

Sumber: data primer (kuisioner) diolah, tahun 2021

Berdasarkan rekapitulasi jawaban responden atas variabel kinerja pada BkkbN Propinsi Sulawesi Tenggara seperti yang disajikan pada Tabel 5 diatas, menunjukkan bahwa deskripsi jawaban responden secara keseluruhan tentang kinerja menyatakan sudah sangat baik dengan nilai rerata 3,81. Artinya bahwa mayoritas responden menyatakan secara keseluruhan mengenai penerapan kinerja meliputi: kuantitas kerja, kualitas kerja, ketangguhan, tanggung jawab dan ketepatan waktu sudah terlaksana dengan baik.

\section{Pengaruh Komitmen Organisasi terhadap Kinerja Pegawai}

Metode Analisis data yang digunakan dalam penelitian ini adalah menggunakan teknik analisis regresi sederhana dengan menggunakan program Statistical Product and Service Solutions (SPSS) versi 24. Hasil analisis SPSS diperoleh uji determinan $\left(\mathrm{R}^{2}\right)$. Kemudian uji hipotesis melalui uji_t. 


\section{a. Uji Signifikan Parsial (Uji_t)}

Uji parsial digunakan untuk mengetahui pengaruh masing- masing variabel independen terhadap variabel dependen (Ghazali, 2013), yaitu dengan membandingkan masing-masing nilai t_statistik dari regresi dengan t_tabel dalam menolak atau menerima hipotesis. Kriteria tersebut sebagai berikut:

1. H0 diterima jika nilai probabilitas (signifikan $\mathrm{t}$ ) $>0,05$ dan $p$ value $>0,05$.

2. H0 ditolak jika nilai probabilitas (signifikan $\mathrm{t}$ ) $<0,05$ dan $p$ value $<0,05$.

Hasil perhitungan regresi sederhana dengan menggunakan aplikasi software SPSS 24 adalah sebagai berikut:

Tabel 6. Hasil perhitungan Regresi sederhana

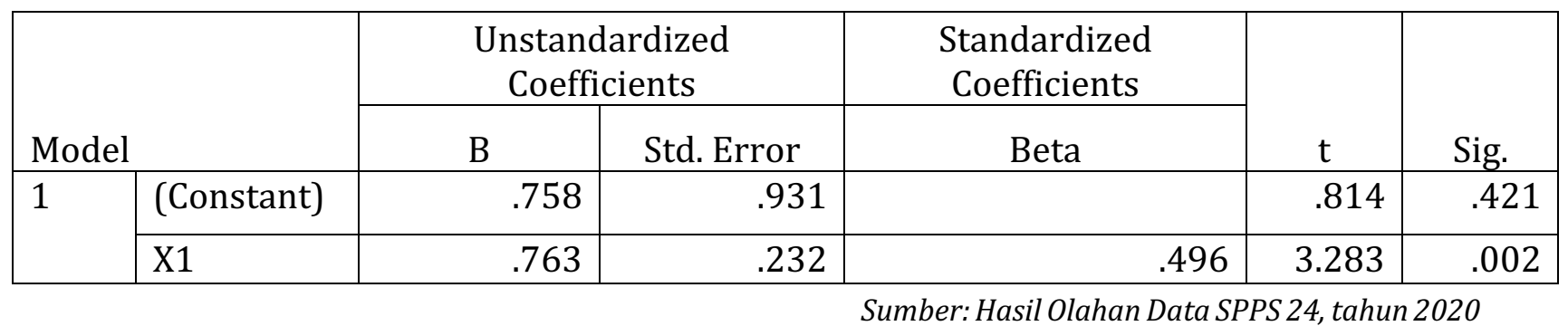

Persamaan rumus regresi sederhana dapat diperoleh hasil sebagai berikut:

$$
\begin{gathered}
(Y)=W_{1} X_{1}+W_{n} X_{n} \\
(Y)=0,496(X 1) \\
(\text { Hair et al., 2010: 4) }
\end{gathered}
$$

Berdasarkan Tabel 6, menunjukkan bahwa nilai koefisien regresi variabel komitmen organisasi (b1) bernilai positif, yaitu 0,496 artinya setiap peningkatan komitmen organisasi sebesar 1 satuan, maka akan meningkatkan kinerja sebesar 0,496 satuan dengan asumsi variabel independen lain nilainya tetap. Kemudian hasil penelitian ini menunjukkan bahwa variabel komitmen organisasi berpengaruh positif dan signifikan terhadap kinerja. Hal ini dapat dijelaskan sebagai berikut:

Variabel komitmen organisasi (X1) berpengaruh positif dan signifikan terhadap kinerja pegawai, hal ini dibuktikan dengan nilai t_hitung $>t$ tabel atau 3,283 $>1,689$ dan nilai signifikan sebesar 0,002 lebih kecil dari $\alpha=0,05$ atau $5 \%$. 


\section{b. Uji Koefisien Determinasi $\left(\mathrm{R}^{\mathbf{2}}\right)$}

Pada model regresi sederhana, koefisien determinasi $\left(R^{2}\right)$ digunakan untuk mengukur tingkat kemampuan model dalam menerangkan variasi pada variabel dependen (Ghazali, 2011). Nilai $\mathrm{R}^{2}$ yang mendekati nol diartikan variabel independen dalam menjelaskan variabel dependen terbatas, sebaliknya jika nilai $\mathrm{R}^{2}$ mendekati satu berarti variabel independen memberikan hampir semua informasi yang diperlukan untuk memprediksi variabel dependen (Ghazali, 2011).

Tabel 7. PengujianKoefisien Determinasi (R²) Model Summaryb

a.

\begin{tabular}{|c|r|r|r|c|}
\hline Model & R & R Square & $\begin{array}{c}\text { Adjusted } \\
\text { R Square }\end{array}$ & $\begin{array}{c}\text { Std. } \\
\text { Error of the } \\
\text { Estimate }\end{array}$ \\
\hline 1 & $.496 \mathrm{a}$ & .246 & .223 & .39058 \\
\hline
\end{tabular}

b. Dependent Variabl: $Y$

Sumber: Hasil Olahan Data SPPS 24, tahun 2021

Berdasarkan Tabel 7 diatas, menunjukkan bahwa nilai $\mathrm{R}^{2}$ adalah 0,496 mengindikasikan bahwa variabel kinerja pegawai $(\mathrm{Y})$ mampu dijelaskan oleh variabel independen berupa komitmen organisasi (X1) atau nilainya sebesar 49,6 persen dan sisanya 50,4 persen dijelaskan oleh variabel lain diluar model penelitian ini.

Mencermati data yang diperoleh, maka penelitian ini dapat memberikan penjelasan bahwa komitmen organisasi berpengaruh positif dan signifikan terhadap kinerja pegawai yang dilakukan oleh penyuluh lapangan keluarga berencana BKKBN propinsi Sulawesi tenggara. Hal ini dibuktikan dengan jawaban jawaban responden secara keseluruhan tentang kinerja menyatakan sudah sangat baik dengan nilai rerata 4,03. Artinya bahwa mayoritas responden menyatakan secara keseluruhan mengenai penerapan kinerja meliputi: affective commitment, continuance commitment dan normative commitment. sudah terlaksana dengan baik.

Kemudian berdasarkan hasil uji parsial analisis regresi komitmen organisasi X1) berpengaruh signifikan terhadap kinerja pegawai. Hal ini sesuai dengan kondisi di lapangan menunjukkan bahwa penyuluh lapangan keluarga berencana terdapat keterikatan emosional untuk terlibat dalam organisasi. Penyuluh lapangan memiliki motivasi dan keinginan untuk berkontribusi terhadap BkkbN.

Penyuluh dengan affective commitment yang tinggi akan bekerja lebih keras dan menunjukkan hasil pekerjaan yang lebih baik dibandingkan dengan yang 
komitmennya lebih rendah. Kemudian penyuluh yang continuance commitmentnya tinggi akan berpengaruh signifikan terhadap kinerjanya karena merasa membutuhkan organisasi tersebut. Lalu, untuk terus mendapatkan manfaat dan untuk mempertahankan keanggotaannya dalam organisasi, penyuluh akan berusaha bekerja dengan baik. Hal ini didukung oleh sistem pemberian tunjangan di lingkungan BkkbN.

Hal ini sesuai dengan teori yang diungkapkan oleh Meyer dan Allen, 1997 menyatakan bahwa komitmen organisasi adalah karakteristik hubungan antara anggota organisasi dengan organisasinya dan memiliki dampak terhadap keputusan individu untuk melanjutkan keanggotaannya dalam berorganisasi. Menurut Robbin dan Judge (2008) menyatakan bahwa komitmen organisasi adalah suatu keadaan dimana seseorang karywan memihak terhadap tujuan-tujuan organisasi serta memiliki keinginan untuk mempertahankan keanggotaannya dalam organisasi tersebut.

Menurut Robert dan Kinicki (dalam Robert Kreitner, 2011) bahwa komitmen organisasi adalah cerminan dimana seorang karyawan dalam mengenali organisasi dan terikat kepada tujuan-tujuannya. Kemudian komitmen organisasi menurut Fred (2005) adalah refleksi loyalitas karyawan dan proses berkelanjutan di mana anggota organisasi mengekspresikan perhatiannya terhadap organisasi serta keyakinan untuk menerima nilai dan tujuan organisasi. Meyer \& Allen dalam Spector (dalam Sopiah, 2008) menjelaskan bahwa komitmen organisasi dapat diartikan sebagai sejauh mana seseorang karyawan mengalami rasa kesatuan dengan organisasi mereka. Hal ini sesuai dengan penelitian yang dilakukan oleh Feri Arif Novan Telaumbanua et al (2019), Rustamadji et al (2019) dan Folorunso, 0.0 et al (2018), menyimpulkan bahwa komitmen organisasi berpengaruh signifikan terhadap kinerja pegawai. Meskipun demikian, ada penelitian berbeda yang dilakukan oleh Aruna Shantha Gamage (2019), yang menyimpulkan bahwa komitmen organisasi tidak berpengaruh signifikan terhadap kinerja pegawai.

\section{Kesimpulan}

Berdasarkan pengujian hipotesis, hasil pembahasan dan temuan penelitian, dapat dikemukakan beberapa kesimpulan sebagai berikut: Jika komitmen organisasi yang terdiri dari affective commitment, continuance commitment dan normative commitment ditingkatkan maka meningkatkan kinerja penyuluh. Artinya bahwa komitmen organisasi pada penyuluh BkkbN sudah sesuai dimana penyuluh memiliki motivasi dan telah merasa nyaman dalam bekerja karena bila tercapai kepuasan yang berkaitan dengan penggajian yang adil tehadap tuntutan pekerjaan, tingkat keterampilan individu, kebijakan promosi yang wajar maka akan meningkatkan 
kinerja. Selain itu penyuluh yang memiliki komitmen afektif akan merasakan adanya ikatan dengan organisasi karena hal-hal dirasakan sendiri oleh penyuluh, bukan dari luar seperti halnya komitmen normatif dan komitmen berkelanjutan, sehingga ada dorongan untuk meningkatkan tanggung jawab dalam kinerja.

\section{Daftar Pustaka}

Abdullah, M. 2014. Manajemen dan Evaluasi Kinerja Karyawan. Yogyakarta : Penerbit Aswaja Pressindo.

Allen \& Meyer.1997. Commitment In The Workplace (Theory, Research and Application). Sage Publication London.

Allen, J. dkk.(2010).Festivals and special event management. (fourth edition). Australia : John Wiley \& Sons Australia, Ltd.

Amstrong, dan Kotler 2003, Dasar-dasar Pemasaran, Jilid 1, Edisi Kesembilan, Penerbit PT. Indeks Gramedia, Jakarta

Anwar Prabu Mangkunegara. (2007). Manajemen Sumber Daya Manusia Perusahaan. Bandung: PT. Remaja Rosdakarya.

Anwar Prabu Mangkunegara. 2009. Evaluasi Kinerja Sumber Daya Manusia. Bandung: Penerbit Refika Aditama.

Aruna Shantha Gamage (2019) The Mediating Effect of Organizational Commitment in the Impact of Transformational Leadership Style on Employee Performance: A Study of Divisional Secretariats in the Jaffna District

Arikunto, S. 2002. Metodologi Penelitian Suatu Pendekatan Proposal. Jakarta: PT. Rineka Cipta.

Arikunto, Suharsimi. (2012). Prosedur Penelitian Suatu Pendekatan Praktek. Jakarta: Rineka Cipta

Bangun, Wilson. 2012. "Manajemen Sumber Daya Manusia”. Jakarta: Erlangga.

Bill Foster dan Karen R. Seeker, 2001 "Pembinaan Untuk Meningkatkan Kinerja Karyawan" penerbit : PT.Toko Gunung Agung Tbk Jakarta,

Bernardin and Russel, 1993. Human Resource Management. New Jersey: International Editions Upper Saddle River, Prentice Hall.

Cooper, Donald R. and Pemela S. Schindler. (2003). Business Research Methods, International Edition, McGraw-Hill Companies, Inc. New York.

David, H. dan Wheelen. 2004. "Manajemen Strategis: Konsep. Edisi ketujuh". PT. Prenhallindo, Jakarta.

David, Fred R. 2005. Manajemen Strategis : Konsep. Jakarta : Salemba Empat

David, Fred R. 2006. Manajemen Strategis : Konsep. Edisi Sepuluh. Jakarta : Salemba Empat

Folorunso, 0.0, Adewale, A. J. dan Abodunde, S.M (2018) Exploring the Effect of Organizational Commitment Dimensions on Employees Performance: An Empirical Evidence from Academic Staff of Oyo State Owned Tertiary Institutions, Nigeria 
Feri Arif Novan Telaumbanua, Sukaria Sinulingga, dan Iskandarini (2019) Effect of Organizational Commitment, Motivation and Job Satisfaction on Employee Performance at Prof. DR. Muhammad Ildrem Mental Hospital

Flippo, Edwin B. 2002. Manajemen Personalia. Jakarta: Erlangga

Ghozali, Imam. 2011. "Aplikasi Analisis Multivariate Dengan Program SPSS". Semarang: Badan Penerbit Universitas Diponegoro.

Griffin, 2004. Komitmen Organisasi. Terjemahan, Jakarta: Erlangga.

Hadari Nawawi. 2004. Manajemen Sumber Daya Manusia. Ghalia Indonesia. Jakarta.

Handoko, T. Hani, 1992. Manajemen, Edisi 2. Yogyakarta: BPFE.

Handoko, T. Hani. 2002. Manajemen Personalia dan Sumber Daya Manusia. Yogyakarta: BPFE.

Isma Coryanata. 2004. -Pelimpahan Wewenang Dan Komitmen Organisasi Dalam Hubungan Antara Partisipasi Penyusunan Anggaran Dan Kinerja Manajerial. Disampaikan Pada Simposium Nasional Akuntansi (Sna) Vii. Denpasar, 2-3 Desember 2004

J. Supranto. 2001. Pengukuran Tingkat Kepuasan Pelanggan Untuk Menaikkan Pangsa Pasar. Jakarta: Rineka Cipta.

J. Supranto. 2005. Pengukuran Tingkat Kepuasan Pelanggan Untuk Menaikkan Pangsa Pasar. Jakarta: Rineka Cipta.

Kosasih, Yonathan Steve dan Eddy Madiono Sutanto. (2014). Pengaruh Budaya dan Komitmen Organisasonal Terhadap Kinerja Karyawan. AGORA Vol. 2. No. 1. Khaerul. Umam. 2010. Perilaku Organisasi. Bandung: Pustaka Setia

Kreitner, Robert dan Angelo Kinicki. 2011. Perilaku Organisasi. Jakarta: Salemba Empat.

L. Mathis, Robert \& H. Jackson, John. 2011. Human Resource Management (edisi 10). Jakarta: Salemba Empat.

Luthans, Fred. 2012. "Perilaku Organisasi". Yogyakarta: Penerbit Andi.

Mathis, Robert.L dan Jackson, John H, 2002. Manajemen Sumber Daya Manusia, Salemba Empat, Jakarta

Mathis, Robert L dan Jackson, John H, 2004. Manajemen Sumber Daya Manusia, Buku ke dua. Salemba Empat. Jakarta

Mathis, R.L. \& J.H. Jackson. 2006. Human Resource Management: Manajemen Sumber Daya Manusia. Terjemahan Dian Angelia. Jakarta: Salemba Empat.

Moorhead, Gregory dan Ricky W. Griffin. 2013. Perilaku Organisasi. Jakarta: Salaemba Empat.

Nazir, Moh. Ph. D. 2009. Metode Penelitian. Jakarta: Ghalia Indonesia

Peraturan Pemerintah Republik Indonesia Nomor 46 tahun 2011 Tentang Penilaian Prestasi Kerja Pegawai Negeri Sipil, penilaian prestasi kerja

Rachmawati. S. R. 2009. "Pengaruh Komitmen Organisasi, Motivasi Kerja, Dan Gaya Kepemimpinan Terhadap Kinerja Karyawan Bidang Keuangan Pada Kabupaten Sukoharjo." Skripsi Tidak Dipublikasikan, Universitas Muhammadiyah Surakarta.

Rahmawati A. 2012. Teori Akuntansi Keuangan. Yogyakarta: Graha Ilmu.

Rivai, Basri, Veithzal dan Sagala, E. J. 2005. Manajemen Sumber Daya Manusia untuk Perusahaan dari Teori ke Praktik. Jakarta: Penerbit Rajawali Pers. 
Rummler, G. A., dan Brache A, P. (1995). Improving Performance: How To Manage the White Space on the Organization Chart. The Jossey-Bass Management Series. Jossey-Bass, Inc., 350 Sansome Street, San Francisco, CA 94104.

Rustamadji and Che Mohd Zulkifli bin Che Omar (2019) The effect of strategic management and organizational commitment on employees' work achievement

Robbins SP, dan Judge, 2008. Perilaku Organisasi. Buku2, Jakarta: Salemba Empat.

Robbins SP, dan Judge, 2009. Perilaku Organisasi. Jakarta: Salemba Empat.

Robbins, Stephen P \& Judge, Timothy A. 2013. Organizational Behavior Edition 15. New Jersey: Pearson Education

Simamora, Henry. 2006. Manajemen Sumberdaya Manusia. Yogyakarta: Sekolah Tinggi Ilmu Ekonomi YKPN. Sugiyono, 2000. Metode Penelitian Bisnis. Cetakan Keduabelas, Alfabeta: Bandung.

Sugiyono. 2011. Metode Penelitian Kuantitatif, Kualitatif dan R\&D. Bandung: Afabeta.

Sutrisno, Edy. 2010. Manajemen Sumber Daya Manusia. Jakarta: Kencana.

Soekidjan. 2009. Manjaemen Sumber Daya Manusia. Jakarta: BumiAksara

Simanjuntak. 2005. Manajemen Dan Evaluasi Kinerja. Jakarta: Fakultas Ekonomi Universitas Indonesia.

Sedarmayanti.2009. Sumber Daya Manusia dan Produktivitas Kerja. Bandung: CV Mandar Maju.

Sekaran, Uma (2003), Research Methods For Business: A Skill Building Aproach, New York-USA: John Wiley and Sons, Inc

Sopiah. (2008). Perilaku Organisasi, Yogyakarta: Andi Offset.

Wibowo, 2007. Manajemen Kinerja. PT. Raja Grafindo Parsada: Jakarta

Wijaya, A. A. M. (2019). Modal Sosial untuk Pengembangan Organisasi: Studi pada Aisyiyah Kota Baubau. JSSH (Jurnal Sains Sosial dan Humaniora), 3(1), 11-20. 